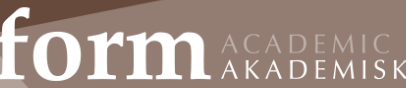

https://doi.org/10.7577/formakademisk.3738

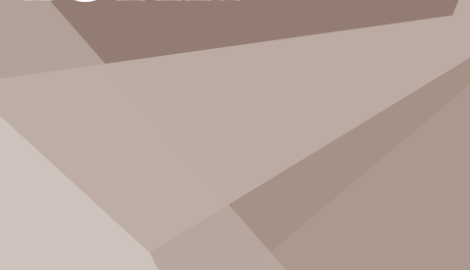

Vol I4, No I (202I)

\title{
Perspectives on aesthetics and vulnerability through the life stories of five young men
}

\begin{abstract}
This article examines what five young men in vulnerable positions tell about their experiences with aesthetics and actualises aesthetics in the context of health and life skills, emphasised in the Norwegian curriculum (2020). For research purposes, an interview with an indirect approach is used to gain insights into these young men's experiences and lives by allowing them to fully play the roles as storytellers. According to the young men's stories, their experiences with aesthetics can be presented through three categories of findings: (1) the connection between their life situations and aesthetics, (2) their emotional moments of aesthetic experiences and (3) their experiences of aesthetics as meaningful phenomena. Furthermore, the findings are discussed against aesthetic theory, which highlights how emotions can be experienced, reflected, symbolised, expressed and sorted out through aesthetics. Thus, a picture of aesthetic experiences is drawn as emotional processes.
\end{abstract}

Keywords:

Young men, vulnerable positions, aesthetic experiences, mental health, curriculum.

\section{MENTAL HEALTH AND AESTHETICS}

Young people's mental health is a current topic in Norway, as mental disorders often occur at a young age (Norwegian Institute of Public Health [NIPH], 2018, p. 8, 2019). The Norwegian Institute of Public Health $(2014$, p. 161,2016$)$ has reported that $15-20 \%$ of all 5-18-year-old children and youth had impaired function due to various mental health challenges, such as depression, anxiety, behaviour problems and so on. Through a closer examination of this proportion, children and youth from families with low socioeconomic status are more exposed to the risk of encountering these challenges. If they live in difficult and conflict-filled home conditions, have difficult relationships with peers or engage in risky activities, they become even more vulnerable (Hegna et al., 2017, pp. 75-77). Furthermore, consequences of mental health challenges are often connected to elements such as suicide, school 
dropouts and marginalisation (Hammer \& Hyggen, 2013; NIPH, 2018). According to statistics, females are over-represented regarding mental health challenges in Norway (Hegna et al., 2017, p. 81; NIPH, 2019). However, boys and young men simultaneously have a higher suicide rate than girls and women (NIPH, 2020), and they drop out of school more often (NOU 2019: 3, pp. 11-12). Of course, there are many possible explanations behind these figures, but there seems to be a tendency for females to seek help to a greater extent than men (Rasmussen \& Dieserud, 2018, p. 2; Regjeringen, 2020, p. 30). It is also suggested that boys and young men may be more vulnerable to environmental factors (NOU 2019: 3, p. 14).

Based on the concern for young people's mental (and physical) health, the revision of the Norwegian curriculum in the autumn of 2020 places a heavy emphasis on how children and youth can cope with their own lives and health. This emphasis has come to the fore as an interdisciplinary topic, called Health and life skills, which has been integrated across subjects and their curricula. The intention is that schools and teachers should be able to equip students with appropriate skills to deal with successes and failures in life, during childhood and youth (Ministry of Education and Research, 2020). Since the interdisciplinary topic is included in the curricula of different subjects, this also involves aesthetic subjects, such as Music and Art \& Crafts. In these subjects, the focus on health and life skills is connected to emotional aspects and the expressive nature of arts, among other things. For example, the Music curriculum states; Music is a resource for recognising, putting into words and dealing with thoughts and feelings, in good times and bad. Artistic expressions provide an opportunity to better understand both one's own and others' emotional lives, and this lays the foundation for good mental health (The Norwegian Directorate for Education and Training, 2020a). Similarly, the Art \& Crafts curriculum states that students are given tools to explore opinions, ideas and feelings and to express themselves through different formats and arenas (The Norwegian Directorate for Education and Training, 2020b). Thus, in the revision of the curriculum, aesthetic expressions are emphasised as sources of emotional enrichment of children and youth, thereby helping mitigate the mentioned challenges regarding young people's mental health.

\section{Young men in vulnerable positions}

Aesthetic values have become important when health research is discussed. The reason for this is how aesthetic phenomena, such as music, art, drama, dance and so on, have been shown to improve people's mental and physical health in various ways (Green et al., 2019, pp. 365-368; Ruud, 2011, pp. 19-21). The research points at how aesthetics is related to the connection between the physical and the mental dimensions, and how different aesthetic expressions interact with people's emotions. The concept of health belongs to such a perspective, a subjective experience of life quality and well-being, rather than an objective definition of someone's state (Ruud, 2011, p. 20). As there seems to be a lack of empirical studies that examine the relations among mental health, social inequality and aesthetics in Norway, I wish to shed light on these topics through a scientific framework, based on data from a longitudinal study and an innovation project in Southeastern Norway. Additionally, the topicality of health and life skills in the Norwegian curriculum seems to make the relation between these elements particularly relevant, and more knowledge should therefore be sought.

Furthermore, given the initially mentioned concerns about boys' and young men's vulnerability, I find it interesting to illuminate these topics from such a perspective. In this study, I therefore examine what five young men, who are or have been in vulnerable positions, tell about their experiences with aesthetic phenomena (such as music and visual expressions) during childhood, youth and early adulthood. What these young men like to do and what they have gone through emotionally in their lives are elements that can provide valuable insights into how aesthetics might interact in vulnerable boys' and young men's lives. However, some clarifications need to be elaborated. First and foremost, it is important to point out that the gender perspective is not discussed beyond promoting the men's viewpoints. Additionally, what these young men tell about aesthetics is primarily related to informal contexts in their spare time. Nevertheless, I wish to deliberately overlook distinctions between formal and informal learning by focusing on how meaning and personal interests outside school can have a 
transferred value to formal education. Naturally, a lot of aesthetic activities take place outside school but still work in parallel with formal education (Austring \& Sørensen, 2006 p. 171).

The young men are called vulnerable for various reasons related to their current or previous positions. They come from families with low socioeconomic status, and after secondary school, they applied for vocational studies. In addition to mental challenges, research has related school dropouts and marginalisation to families with low socioeconomic status. Students attending vocational courses are also over-represented in these statistics (Markussen, 2016, pp. 28-33). At the time of writing this article, three of the young men have discontinued their education and are unemployed, while the other two are still studying or working. The young men tell different stories about growing up that reflect how they struggled mentally in various ways. Elements such as bullying, substance abuse, depression, anxiety, unstable family relationships, violence in close relationships and learning difficulties are included in their stories. Vulnerability is thus presented as a multidimensional state that takes place in different contexts across these men's lives. By using the term vulnerable positions, I do not foresee these young men as being marginalised or diagnosed with mental illness in their future lives. I rather highlight the risks and the vulnerability that follow these positions (Hammer \& Hyggen, 2013, pp. 16-17; Markussen, 2016, p. 45).

The overall aim of my study is to shed light on social inequality, as well as highlight the role that aesthetic subjects may play in vulnerable young people's mental health. I also believe that the perspectives of young men can contribute to this field of knowledge. Therefore, the young men's vulnerability appears to be an interesting element to study in order to understand what aesthetics offers them while coping with everyday life. This is examined through this research question: What do young men in vulnerable positions tell about their experiences with aesthetics? The study also has a qualitative, narrative research design, based on Dewey's (1958) naturalistic philosophy, which emphasises the acknowledgement of experience. Such a design needs a method that can gain insights into personal experiences by building the study participants' trust and confidence in the researcher. An interview technique called the indirect approach (Moshuus \& Eide, 2016) has thus been used to let the informants lead the conversation based on their own perspectives. The empirical material consists of eleven interviews and field notes, which have been analysed both narratively and thematically (Thagaard, 2013).

\section{AESTHETIC EXPERIENCES, COMMUNICATION AND SPACES}

In this study, the term aesthetics is approached from John Dewey's $(1934 ; 2008)$ perspective on humans' perception and enjoyment of art. In contradiction to the traditional view on aesthetics as an object of high culture, Dewey presents the term aesthetic experiences as a value in people's everyday lives. Dewey (as cited in Hohr, 2010, p. 21) highlights that art could create new prospects, open people's eyes to what might be hidden and renew their understanding.

From Dewey's (2001, pp. 53-55; 2008, pp. 211-213) perspective, aesthetic experiences can be understood as relational experiences, where individuals continuously interact with the environment, the culture and the world around them. This implies that every experience consists of both passive and active elements that involve a connection between the activity and the exposure to its consequences. According to Dewey (2008, p. 212-213), this interaction between humans and the environment will counteract the monotony and meaningless repetition in their lives. All experiences that people undergo are therefore based on doing something and reviewing something. However, the quality that signifies an experience and is of an emotional character is what Dewey (2008, pp. 210-212) calls an aesthetic quality. He claims that an aesthetic experience stands out as a strong, emotional experience because of the aesthetic, emotional quality's dominance over the whole experience. This means that it occurs in processes, moments and highlights where everything else is forgotten. All resistance, tension and excitement will in this way be transformed into a consummate conclusion. The aesthetic experience also includes a phase that involves people completely. They immerse themselves in something, using all their energy and intensity. As the energy flows, the controlled activities can be perceived as highly intense moments when humans are filled with emotions. From such a perspective, emotions become 
aspects of a complex experience, which are moving, changing and at the same time connected to objects and actions.

Mihaly Csikszentmihalyi's (1990) concept of flow has several similarities to the aesthetic experience and is described as a condition where the sense of time and place is forgotten (Fredricks et al., 2004, p. 63). In these moments, an individual is in full control of one's mental energy, and the mind is stretched to achieve something meaningful (Csikszentmihalyi, 1990, pp. 3, 41). Csikszentmihalyi (1990, p. 51) believes that activities that provide joy are often designed precisely to achieve this, and activities such as engaging in sports, literature and art have been developed over centuries for the purpose of enriching life. For example, Csikszentmihalyi (1990, p. 3) refers to the condition or feeling of an artist creating a work of art: "It is what painters feel when the colors on the canvas begin to set up a magnetic tension with each other, and a new thing, a living form, takes shape in front of the astonished creator." Csikszentmihalyi (1990, p. 3) claims that a sense of control follows, and a deep sense of joy and excitement arises.

Furthermore, Hansjörg Hohr's $(2010,2015)$ perspectives built on Dewey's approach to experiences but simultaneously expands these ideas by illuminating how people use various art forms as mediums to experience. Hohr $(2015$, p. 2) also refers to the term presentative symbolism, coined by Susanne Langer (1942), to describe the symbolism that characterises mediums that are associated with art, music, dance and so on. To summarise, presentative symbolism can be described as a symbolic expression that represents an experience, a feeling or an object. As mentioned, this can be mediated through the many and diverse symbolic languages of art (Austring \& Sørensen, 2010, p. 45). Presentative symbolism is known through its unique shape, consisting of a pattern and a structure that contrast the random and chaotic form. For example, a picture or a piece of music is framed by its unique structure. At the same time, its pattern refers to life experiences that are based on common references of different phenomena, which can be feelings, such as loneliness, love or another phenomenon. In this way, presentative symbolism communicates an emotional message. It articulates the invisible that can be difficult to express in exact ways (Hohr, 2015, pp. 2-4). For example, these can be subjective experiences that appear fragmented, silent or unclear. In other words, these experiences can contain complex and emotional aspects that are difficult to capture in an accurate or discursive formulation (Austring \& Sørensen, 2010, p. 46). The opposite of presentative symbolism is discursive symbolism, which can be understood accurately and consists of statements. For example, discursive symbolism works well in a report, since there should be no space for interpretations. However, discursive symbolism works against its purpose in an emotional message, as it is emotionally neutral. Here, presentative communication conveys emotional messages in a more appropriate way (Hohr, 2015, pp. 2-4). Hohr (2015, pp. 3-4) claims that communication based on presentative symbolism is a kind of aesthetic communication. It can contribute to framing human experiences, which arise when people interact with the world.

From a psychoanalytical perspective, aesthetic experiences and practices have also been applied as creations of symbols that take place in a potential space. Donald Winnicott (1971, pp. 169171) uses this concept to describe a sphere of living experiences that bridges the inner core, hence the humans as subjects, to the outer core, which is the world surrounding humans. Between these two boundaries, Winnicott (1971, pp.169-171) refers to the potential space as a place where cultural and aesthetic experiences (as well as a child's creative play) have the opportunity to unfold. In this way, he introduces a third world, where humans can be creative, share their subjective experiences and develop an understanding of the world and of others (Austring \& Sørensen, 2006, p. 203; 2010, pp. 48-49). Although such psychoanalytical ideas and theories might be outdated today, the potential space can still create an image of how aesthetic activities contribute to connecting the individual to the world. Additionally, the potential space sheds light on how the individual is given the opportunity to act in a sphere that feels natural and thus involves a kind of freedom. Malcolm Ross (1978, pp. 52-53) has further developed these theories and refers to how aesthetic experiences can create a balance between the inner and the outer worlds. A result of this balance is that humans develop a sort of intelligence of feeling. This can be understood as an emotional process of adaption, where the individual becomes capable of handling experiences in an emotionally appropriate way. Ross (1978, p. 52) expresses this as follows: "We need to express ourselves when we sense that our feelings need sorting out. They need to 
be sorted out because we are having difficulty in assimilating them." Therefore, Ross (1978, pp. 52-53) approaches aesthetic expression as a kind of "emotional sorting machine". Through creative selfexpression, people can thus sort out their feelings and emotions, which constitute an aesthetic impulse.

Altogether, the theoretical perspectives of Csikszentmihalyi (1990), Dewey $(2001,2008)$ and Hohr (2010, 2015), as well as the psychoanalytical perspectives, represented by Ross (1978) and Winnicott (1971), offer a framework to understand aesthetic experience as a scientific concept. The perspectives depict an aesthetic experience as unique. Through its emotional character and special symbolism, the experience contributes to enriching life, counteracting meaningless repetition, communicating unclear or fragmented experiences and opening spaces where emotions can be sorted out. In this respect, aesthetic experiences differ from other experiences in life and should be considered according to the qualities they possess.

\section{AN INDIRECT APPROACH, FRAMED BY DEWEY'S NATURALISM}

According to the theoretical framework, with Dewey as an important contributor, it seems useful to envelope the study in Dewey's (1958) own naturalistic philosophy. This implies that Dewey (1958, pp. 1-5) acknowledges experience as a fundamental ontological category, since nature and reality are presented through human experiences. According to Dewey (1958, pp. 1-5), experiences that represent something aesthetically are therefore just as real as experiences that represent the material world. However, to gain insights into these aesthetic experiences, researchers need a suitable design and measure to interact with the informants. By using a qualitative, narrative design, the intention is to facilitate a trusting interaction, where an indirect interview technique (Moshuus \& Eide, 2016) gives the informants the opportunity to fully occupy the positions as storytellers. The indirect approach is based on the idea that the researcher interacts with the informants in an informal conversation, which promotes their subjective experiences and own perspectives. This means that the informants lead the conversations regarding what they want to talk about and emphasise. The data collection will therefore result in unique interviews with various themes and degrees of relevance. During the conversation, it is also important to search for signs that allow researchers to obtain insights into the informant's context and secret world (Bunting \& Moshuus, 2017, pp. 5-7; Moshuus \& Eide, 2016, pp. 5-7).

The indirect approach is used as a common method in an international innovation project, called Marginalisation and Co-created Education (MaCE), and a longitudinal study in Southeastern Norway, named Young People, Education and Early School Leaving in Telemark (UngSA). Both MaCE and UngSA have examined marginalisation in the educational system by focusing on young people's life stories (University of South-Eastern Norway, n.d.a, n.d.b). Altogether, MaCE and UngSA possess recorded and transcribed interviews with 131 informants, recruited from high schools, the Norwegian Labour and Welfare Administration (NAV) and other welfare institutions. My selection consists of five young men in vulnerable positions, between the ages of 17 and 21 years. I interviewed two of them during my participation in MaCE, while three interviewees were recruited from UngSA's database. This can be regarded as a purposeful sampling strategy (Creswell, 2013, pp. 154-155), though these young men generally and voluntarily talked about aesthetic phenomena during the interviews.

To maintain confidentiality, the informants have been given the fictitious names of Richard, Tom, Mikkel, Kim and Peter. In addition to the other formal considerations, such as the informants' consents and security in data storage, several ethical issues related to the interview situation (Kvale \& Brinkmann, 2015, p. 97) have been considered. Keywords such as power and asymmetric relations (Kvale \& Brinkmann, 2015, pp. 52-55) in the interaction with vulnerable groups (Moshuus, 2012) have therefore been carefully discussed. Taking these aspects into account, it is desirable to approach these young men's stories with the aim of preserving their perspectives and highlighting what is real in their worlds. This is done through a narrative analysis, which focuses on chronology, patterns and the interpretation of life experiences (Thagaard, 2013, pp. 128-131). The stories are therefore presented through themes (Thagaard, 2013, p. 171) regarding aesthetics, framed by these young men's unique life experiences. 


\section{THE YOUNG MEN'S EXPERIENCES WITH AESTHETICS}

According to the stories of Richard, Tom, Mikkel, Kim and Peter, these young men are interested in aesthetics phenomena, such as music and visual expressions. In their interviews, they talk voluntarily and generally about music, and one of them also likes to draw and paint. To understand what the five men tell about these phenomena and what these seem to offer them, the stories are divided into three categories of findings. Each category is presented through various selected examples and excerpts, with the aim of being illustrative. However, the categories might be artificial or overlapping. For example, many of the quotes can reflect elements across the three categories. The choice of presenting the findings in such a way is nevertheless based on the idea that smaller pieces can create a picture of understanding. Thus, the first category is the recurrent connection between aesthetics and the young men's life situations. The second is how the young men describe moments of their aesthetic experiences. The third is how aesthetics seem to be meaningful phenomena for these men to spend time on

\section{Connection between aesthetics and life situations}

When the young men talk about either music or art, it seems to consistently involve a connection between their life situations and aesthetic expressions or experiences. In various ways, the men highlight elements from their life situations when they explain how they use aesthetic phenomena in their everyday lives. For example, 17-year-old Richard, who is enrolled in vocational studies, says that he has been systematically bullied by fellow students since he was a child. He still experiences some bullying in vocational school but to a lesser extent than in the past. According to him, the bullying has adversely affected his mental health and triggered thoughts about suicide. In contrast, music is what Richard calls "one of my greatest joys in life". He plays a corps instrument in his spare time, listens to music every day, attends music festivals once in a while and has nice experiences from the music lessons in school. In this quote, Richard explains that music makes him forget about bad days:

Such as if we say then, that you come home and have had a very hard day. And put on some deep notes from The Art Is Murder. For example, Holy War, which is just heavy guitar riffs, big drum bows and a deep bass and a vocalist who is losing his throat. Then, it's just what you focus on, and then, then you don't think of everything that has happened.

Richard highlights the song's instrumentation by using such adjectives as heavy, big and deep. As these adjectives seem to have some similarities, while expressing something dark and dramatic, Richard might connect his experiences from school and life to the elements in the music. At the same time, Richard's music can be perceived as an expression of his emotional state, while he tries to shift the focus away from what is painful and frustrating. Thus, there seems to be a connection between this aesthetic expression and the life situation in which he sees himself.

Tom, another young man, generally tells about his interest in rap music. He composes raps for various beats he finds on YouTube and writes lyrics. Now 18 years old, he lives in a child welfare institution. According to Tom's story, he grew up with unstable family relationships and substance abuse and started taking drugs at the age of 13 . As a result, he stopped attending secondary school and dropped out of vocational studies. After moving around from foster care and institutions, he is now trying to become drug-free and distance himself from the social network to which he has belonged for many years. At the same time as Tom is trying to start a new life for himself, he starts to question his previous raps and lyrics:

So, yeah, I have always loved rap music, but when I finally came out of that social environment, I thought I had to stop listening to the music I like. But I can't do that, I guess. So, I just have to find my own thing. Because when I started to rap, it was often negatively. I was rapping about everything that was crap and bad. I can't even say everything I've been rapping about, but... so I turned it around and made it into a good rap. 
The change from negative lyrics to what Tom calls a "good rap" takes place at the same time as he distances himself from drugs and his previous social network. Thus, there seems to be a parallel between his own struggle and the choice of finding a new direction in music. In this way, these changes or dilemmas might represent more than single lyrics or compositions. They may symbolise the journey that he has been going through or what he wants to be in the future. Therefore, the lyrics and the raps can be perceived as reflections or symbols of other elements in Tom's life.

Twenty-year-old Peter consistently talks about his interest in and passion for music. He has dropped out of vocational studies twice and is neither studying nor working. During Peter's adolescence, he started to develop mental problems and is now diagnosed with a mental disorder. Because of his mental health issues, he had a lot of absences from school, and during ninth grade, he refused to attend school. Instead, he started to replace the school days with music and played the guitar for hours every day. Throughout Peter's teen years and until now, he therefore continues to play and at the same time, composes songs and periodically plays in a band. Peter says that he often struggles to find joy in life when he is depressed, but he still manages to find positive thoughts when he plays music:

Yes, considering that if you first get depressed, it is easy to forget the things you like and the pleasure of it. It feels like you're not getting anything out of the things you like when you are depressed. But sometimes I come back, and then somehow, somehow... eh... yes. When I practise with my band, it's kind of... I kind of manage to forget all the depressive thoughts in a way and start to think about the things I like about playing music.

In this quote, when Peter tells about his experiences with music, he automatically draws a line to his mental state, hence his depression. He tells us that he manages to change his mood while playing music and that these experiences seem to contrast other elements regarding his mental state. He uses the clause "forget all the depressive thoughts" when he describes how music impacts his mental state. Although music becomes a counterpart to other experiences in Peter's life, it still enters into a variety of life experiences where no one seems to be isolated from another.

\section{Moments of aesthetic experiences}

The five young men describe very personal moments in which they immerse themselves in aesthetic experiences of music or visual expression. The moments are presented in various ways, but a recurrent element is the emotional aspect described. This means the young men's feeling of being relaxed or happy, the ability to express emotions or feelings, the experience of comfort and the state of mind where they lose their sense of time and place. For example, through his own story, Kim appears as a happy boy/young man, enjoying sports. Now 20 years old, he has completed his vocational education. Kim's story indicates a nice childhood with kind parents and many friends. He still found primary and secondary school boring, and when he took up vocational studies, he had many low grades. According to him, his low grades were related to his learning disabilities and his behaviour in school. In his teenage years, several changes also occurred in his life. His parents got divorced, and a close family member died. Kim says that his emotional state changed as a result of these events. During this period, he felt depressed, and for the first time in his life, he says he experienced grief. Later, Kim says that his grandfather used to paint with him when he was a child. After his grandfather's death, Kim inherited the art materials and continued to use them. He mentions being inspired by colours while he is using the canvas to create quite personal paintings. In primary and secondary school, Kim was also quite fond of Art \& Crafts, and he says that he liked to work with his body and hands. In this quote, Kim tries to describe what he does when he paints at home:

Yeah, because I feel like I'm expressing myself then... Ehh... Without knowing how to do it, I pull my inside out. Without knowing how to do it in a way. So, I'm like that; I put the feelings in the colours and in the pictures. 
Clearly, Kim finds it difficult to describe exactly what happens when he paints. He relates to his emotions by using the expression "my inside". When he paints, he also says that he "puts the feelings in the colours and in the pictures". Based on this, this quote can be understood as a way to express emotions through aesthetics. As mentioned, the pictures are very personal, and he prefers not to show them to his friends and family. This might indicate that it is difficult for Kim to separate his feelings from the paintings. A little later in the interview, Kim describes painting in another way. He says that he uses painting, as well as music, as a way to relax. While using terms such as "delicious" and "relaxing", it may seem that Kim experiences aesthetics through his body, which can be reminders of a kind of meditation.

Another informant, Mikkel, generally tells about his interest in music. According to him, he grew up with unstable family relationships, violence and substance abuse and as a result, spent several years in foster care. Now 20 years old, he has completed two years of vocational school but is neither studying nor working. He has applied for many jobs but says that no one will hire a young man without work experience. Mikkel says that he had a lot of absence and no motivation while pursuing vocational education. However, music is a huge part of Mikkel's life. For a year, Mikkel took up music studies, referring to it as the "best year of my life". Mikkel says that he can play his guitar for hours and started to practise as a teen. In this quote, he tells about his interest in playing the guitar and what it has meant for him when life has been difficult:

It's been that way, the way I've got things out that I haven't managed to say then... I don't know. If I'm sorry, then I play the guitar. Either I play sad songs, or I play something happy; that puts me automatically in a better mood. But it's really just such things I do all the time. I try to use it as something to turn my mood around.

In this quote, it seems that Mikkel describes his guitar playing as a way of expressing emotions that are difficult to put into words. The aesthetic expression can therefore be perceived as an expression of emotion or a way to express emotion through aesthetics. He also emphasises playing as a way to change his mood or state of mind. In this way, it seems that music serves as a kind of comfort because it helps Mikkel feel better in these particular moments.

Returning to Tom, the addict who has a special interest in rap music, he also tells about the moments when he can sit and compose lyrics and rap to the beats he finds on YouTube. Without school, work, a girlfriend or a social network, Tom describes the days as long, boring and frustrating. He is worried about his future and how life will turn out to be. Tom explains that when he is composing, he forgets the situation and the things that worry him:

Yes, I must wait and see what happens in the future. That's where I'm so.... Also, I have some days when I'm really happy, but that's why I need that rap because then I forget all this, what's going on and girls and ladies. Then I'm somehow [claps his hands], then I'm just there. Love it, just forget everything. That's why I need it.

In the preceding quote, Tom seems to feel joy and enthusiasm while he is making music and interacting in the creative process. He uses the clause "then I'm just there" and describes a state where he is completely involved in the moment. In another part of the interview, he also uses the clause "when I get that flow". These expressions may show that Tom has experiences of a very emotional and positive character, representing a counterpart to other elements of his everyday life. Therefore, these moments can be understood as offering an opportunity for him to take a break from things that worry him.

\section{Aesthetics as meaningful phenomena}

The five young men generally tell that they spend a lot of time on activities such as practising to play an instrument, listening to music or painting. Thus, there are not just moments or highlights portrayed during these stories but also long-term practice, rehearsing and creative work. Therefore, it seems appropriate to say that aesthetics become meaningful phenomena for these men to spend time on, as it becomes an alternative to the inactivity and indifference that characterise a part of their everyday 
lives. For example, Peter, the young man who has struggled with his mental disorder since he was a teenager, says that music is almost the only thing he has managed to do in certain periods. As mentioned, Peter's mental health challenges developed so that he mostly stayed home during secondary school. In this period, Peter explains that he had no social network, and music turned out to be the only activity with which he could fill his days:

Interviewer: Yes. But when you were sad, did you have the music you were interested in? Peter: Yeah but not before, like when that depression started in eighth grade, then I started to spend more time on music. Not necessarily because it was the only thing I was interested in. Interviewer: No.

Peter: It was like one of the only things I could do, since I had nobody I knew. I had no friends to join. I did not.... I've never enjoyed playing games, as most people at my age often do. So then, I started to spend more time on music, and as I spent more time, I became more interested.

Peter mentions that music became an activity that he could manage to do at home although he struggled with his health and had no friends. He also describes the ripple effect of practising frequently by explaining the interest that followed. Thus, it seems that Peter finds meaning in spending time on music and thus carries on with this activity. Based on his story, with elements of mental health issues, dropout and social isolation, it is also possible to view music as an alternative to the passivity, lack of energy and inactivity that greatly characterise his life.

Not so different from Peter, Kim mentions that he often spends time on painting. He says that he does not feel particularly good in painting, but he keeps on doing it because he thinks it is much fun. It is not the result that matters to Kim but the fact that he enjoys painting and how it relaxes him. As mentioned previously, the pictures are very personal to Kim and he would rather not show them to others. Kim also describes the activity of painting as something that can keep him busy for hours:

Kim: So it is very nice and also relaxing to sit and listen to music and paint for hours in the evenings. It is delicious.

Interviewer: Is that your way to relax?

Kim: Yes. That's a lot like... the same as watching a TV show.

Although Kim does not like to show his paintings to his friends or family, he still invests a lot of time and energy on creating and justifies it by comparing it to relaxation. Additionally, Kim was a sporty boy, who devoted a lot of time to football and had his social network in this context. Altogether, there does not seem to be any need for recognition or fame regarding the paintings in Kim's story. On the contrary, it is the activity itself that drives this initiative forward and that Kim experiences as meaningful.

Mikkel, who had to be placed under foster care when he was a teenager, also says that he has played and still plays the guitar every day. Today, he is not enrolled in any educational programme and has no job. In certain periods, Mikkel used to follow local musicians wherever they held concerts in the district and to study their skills and musical level. Afterwards, he compared them with himself and his own skills. This story, similar to many others, shows Mikkel's particular interest in details and musical technical skills. When he practises using these skills and techniques, he often describes a state of mind where he immerses himself in the music and thus forgets elementary things, such as eating and going to the toilet. Here, Mikkel describes such moments, where he practises and uses videos on YouTube to learn:

Mikkel: There was a period when I could sit eight hours a day. Interviewer: Oh.

Mikkel: And do nothing but that. And all I did was sit for eight hours in front of the PC, and then there was no eating, no going to the bathroom, no other things.

Interviewer: Did you sit all day?

Mikkel: Yes, I sat completely still and just played the guitar. 
In this quote, the activity becomes so immersive that Mikkel disappears into another world, where time stands still. As a result, he spends several hours rehearsing and immersing himself in the music. If also referring to Mikkel's situation where he has no job or educational programme to spend time on, it might be imagined that he has a lot of spare time. The music activity can thus be interpreted as something that keeps Mikkel in a process of learning and becomes an important element of his everyday life. In the summary of Mikkel's story, music can thus be perceived as a meaningful phenomenon for him to spend time on.

\section{AESTHETIC EXPERIENCES AS EMOTIONAL PROCESSES}

Looking back at the three categories of findings, they all seem to reflect different emotional aspects of experiences with aesthetics. The reason for this is how Richard, Tom, Mikkel, Kim and Peter connect them to what they are going through on an emotional level in their own life situations, what they experience emotionally when they express themselves or receive aesthetically, and what they enjoy, prefer and find meaningful. Furthermore, I rely on the presented theories in an attempt to provide an understanding of what these emotional aspects comprise and why they seem to be recurrent elements.

As shown, the young men's experiences with aesthetics are often related to their life situations in various ways. For example, Tom says that he wants to become drug-free at the same time as he wishes to compose positively charged raps. A similar example can be found in Richard's story, when he connects his aggressive musical expression to his bad days of being bullied at school. While talking about the bullying in school and how it has affected him mentally, Richard simultaneously talks about music. Through the story, it therefore seems natural for Richard to relate his aesthetic expressions to his emotional state of frustration, anger and dark thoughts. Thus, experiences with aesthetics do not seem to exist beyond his life situations and experiences. Theoretically, Dewey (2008, pp. 197-198) and Winnicott (1971, pp. 196-197) highlight this connection based on different figurative descriptions, either as continuous movements or as spaces that bridge the gap between the subjects and the world. On one hand, Dewey (2008, pp. 197-198) claims that every experience consists of elements that must be viewed in context with each other. He compares them to waves that follow each other in a storm but are simultaneously parts of each other. Thus, every phase of an experience has its own uniqueness, and at the same time, all phases constitute a whole. On the other hand, Winnicott (1971, pp. 196-197) refers to how experiences with aesthetics take place in a potential space that is culturally conditioned and exists between the individuals and the environment around them. As Winnicott refers to these as "living experiences", they might reflect something real, authentic or relational in the young men's lives.

From another perspective, this connection might represent something symbolic that reflects elements from these young men's life situations. For example, the following questions can be raised: Why is it so hard for Tom to continue with his rebellious rap music when he no longer wants to be a drug addict? Why is it so difficult for him to leave the music that he has followed through his teen years? Of course, this can be related to Tom's identity and what he wants to be in the future. Nonetheless, the aesthetic expression might represent something beyond this, which might be difficult to capture. Looking closer at Tom's story reveals that he grew up with parents who used drugs, was moved from home as a child, lived in a foster care home as well as several institutions, and started to use drugs as a teenager. Told from Tom's subjective perspective, these life experiences seem to be presented as simple changes in life and appear to have unclear framing. However, referring to Hohr's (2015, pp. 3-4) description of aesthetic communication and its special symbolism, this unclear framing may be more clearly. Hohr uses the term presentative symbolism to explain how the unique structure of songs, paintings or other art forms frames a pattern or a message. In this case, the message can consist of a pattern that refers to the young men's emotional, complex experiences. These emotional and complex experiences are difficult to shape through exact and accurate descriptions; as a result, presentative symbolism becomes more suitable for experiences or emotions that may be unclear or fragmented (Austring \& Sørensen, 2010, p. 46). The men's aesthetic expressions can therefore present something that may not necessarily be easily definable - something that captures their experiences from life and makes something perceptible out of it. 
Furthermore, the young men's moments of aesthetic experiences seem to have a clear emotional aspect, as they occur as comforting or enjoyable elements in these men's lives. The men convey various elements, such as feeling relaxed or happy, the experience of mood changes, which often feel comforting, or how they often, in small moments, forget something that feels difficult in their own life situations. For example, Kim says that it feels "delicious" and "relaxing" to sit and paint and listen to music. Another example is how Mikkel acknowledges that music has helped him turn his mood around when life has been difficult. As Mikkel had to leave his family during his teen years and he now spends a lot of time playing the guitar, it can be imagined that music has become a stable and comforting element in his life. Turning again to Dewey (2008), he pictures a natural consequence of experiencing something aesthetically as the possibility of being totally focused on and involved in aesthetic expressions. To elaborate on this, Dewey (2008, pp. 212-213) claims that aesthetic experiences will promote such moments (as the young men describe) when everything else is forgotten and all resistance and tensions are gone. Consequently, these moments will merge with fulfilments, with which Dewey counteracts meaningless repetition and monotony in human lives. Therefore, Dewey considers these experiences as sources of enriching life, as they make people feel intense and alive in such moment of life. As mentioned, these bear similarities to Csikszentmihalyi's (1990, pp. 3, 41) concept of flow, the state of mind where people forget time and place, and their psychic energy is in full control. Tom, the addict who dropped out of school and has no job or social network, also uses this expression, as he says "when I get that flow" and describes moments when he is totally focused on and involved in composing raps. However, it is worth discussing whether the men's reactions are just diversions, pastime or joy caused by random activities of personal interest. Csikszentmihalyi (1990) never limits the concept of flow to deal with aesthetics but argues that music/art phenomena are often perceived in this context. The consequence of such argumentation might be that aesthetics is presented as a random activity, juxtaposed with games, sports and so on.

In this regard, what aspects of the men's statements can provide a clearer explanation in terms of describing the qualities of aesthetics in such ways, making it differ from other joyful activities, such as games or sports? An answer might be that some of the men find it easier to express themselves aesthetically than to find words to describe what might be good, painful or difficult. For example, referring to Kim's story, he does not know what happens when he paints but describes it as a way of pulling the inside out or putting his feelings into colours and pictures. As Kim also experienced grief due to his parents' divorce and the death of a family member, this might be a way for him to convey his thoughts, feelings and experiences through visual expressions. Similarly, Mikkel says that he expresses himself by playing the guitar as a replacement for words that might be hard to find. Such a statement may indicate that aesthetics seems appropriate as a form of communication when it is difficult to describe unclear and fragmented feelings and thoughts, as well as verbalise them in exact words. Thus, this discussion can return to presentative symbolism, as described by Hohr (2015, pp. 3-4, 10), who claims that aesthetic communication has a unique character because it articulates the invisible. The structures and patterns of songs, instrumental music, shapes and colours can then create alternative ways for these men to communicate and frame the invisible into something concrete. Ross (1978, p. 53) emphasises these aspects by using the term aesthetic impulse. Ross points at how experiences from life constitute a kind of impulse that is converted into form through expressive acts. Here, Ross shows how humans sort out what they need to sort out, thus creating something unique for themselves. From Ross' perspective, the men's aesthetic expressions can therefore be pictured as a kind of "emotional sorting machine", where difficult and painful emotions emerge into form. In this way, the young men seem to create a better balance between themselves and the outer world, as well as give them a greater opportunity to handle experiences from everyday life. As mentioned, Ross calls this an intelligence of feeling and emphasises the value it might have for the individual's ability to control one's own emotional state and life.

In addition to all the emotional moments in these stories, it also takes broader perspectives regarding time and scope, where a lot of hard work is integrated. For example, Mikkel has practised playing guitar frequently and regularly since his teen years, often for hours at a time. Similarly, Peter, whose serious depression made him drop out twice from vocational school, liked to spend time on 
music, and in most of his teen years, this was almost all he managed to do. A consequence of this activity is that Peter has become more interested in music and has managed to play and forget about depressive thoughts. Such active moments, when the individual has gathered one's psychological energy and when one's mind and senses are focused, show that these activities might become contradictions to inactivity and indifference for these boys. Csikszentmihalyi $(1990$, pp. 42, 51) argues that such activities that present joy have been designed and developed over the centuries for the purpose of enriching life. This is also expressed more or less directly or indirectly through the young men's stories, which indicate that aesthetics give meaning to life. For example, Richard points at music as "one of my greatest joys in life". Csikszentmihalyi (1990, p. 51) also believes that conditions that emerge from these activities could promote feelings of control and satisfaction, not only according to a person's self-esteem, but also to other people or to the rest of the world. By acting freely and enjoying something for its own sake, something consequently happens to a person and keeps one continuing this activity.

\section{IMPLICATIONS FOR FORMAL EDUCATION}

To summarise, it can be implied that the young men's aesthetic experiences are included in the continuous movements of their experiences and have symbolic aspects that reflect their life situations in various ways. Aesthetic phenomena also seem to enrich the men's lives through emotional moments and long-time practice by giving them comfort, joy, satisfaction, meaning and a useful medium to communicate. Thus, experiences with aesthetics appear through these stories as mutual emotional processes, where a range of emotional aspects turn into perceptual expressions, which again return to the emotional self. In this way, the findings and the discussion illuminate the needs of these young men (and earlier as boys) to process difficult experiences from their everyday lives through aesthetic expressions. As it is also known that the risk of having mental health issues increases the lower a person's socioeconomic status is, along with several negative life experiences (Hegna et al., 2017; NIPH, 2018), in the findings and the discussion, it is emphasised why these emotional processes might be significant for these men.

The stories in this article are primarily related to informal contexts in the young men's spare time. However, three of them - Richard, Kim and Mikkel - also mention that they either liked or have had positive experiences with either art and crafts or music in the school context. Thus, experiences with aesthetics at leisure might have a transfer value that should be further discussed. According to Austring \& Sørensen (2006, pp. 171-172), aesthetic practices equip children and youth with the ability to learn a language that can be further applied in learning processes, regardless of location and context. This language can open doors to vitality and knowledge within themselves of which young people might be unaware. Moreover, when aesthetic practices take place in formal education, they also expand or double. This implies that they move from being subjective to collective. The individuals do not only connect and reflect the aesthetics to their own subjective experiences but additionally through the aesthetic expressions of others. Thus, despite what comes first or second, the subjective or the collective, aesthetic experiences can be transferred between contexts. Previous research has also pointed at how personal interests and meaning created outside formal education become catalysts for learning in school (Biesta et al., 2004).

However, it cannot be taken for granted that students have experiences with aesthetics that are similar to those described in these young men's stories. There might even be vulnerable children and youth who have never been introduced to any of these experiences. From such a perspective, formal education can be an important arena to introduce children and youth to aesthetic phenomena and allow them to experience these as emotional processes. Hohr (2015, p. 4) emphasises a similar perspective, pointing at the ability to experience aesthetic expressions as learned. Hohr (2015, p. 4) claims that humans do not automatically enjoy all kinds of aesthetic experiences. Rock, folk music, jazz or blues are examples of aesthetic forms that carry their own cultural symbols and histories and that need to be processed and experienced over time in order to be enjoyed and understood (Austring \& Sørensen, 2010, pp. 42-43). Thus, to be expressive through aesthetics, these systems of symbols need to be learned and understood (Hohr, 2015, p. 4; Austring \& Sørensen, 2010, pp. 45-47). If the school 
succeeds in doing so, children and youth might develop the ability to create a better balance between themselves and the outer world (Ross, 1978).

Based on these considerations, the educational context should acknowledge the qualities of aesthetic phenomena and use them to promote good mental health among students. To do so, schools need teachers who recognise the value of aesthetics in vulnerable young people's lives. Additionally, I hope that the Norwegian focus on health and life skills in aesthetic subjects and their curricula will be taken seriously and grounded in science.

\section{CONCLUDING MARKS}

The picture drawn of aesthetic experiences in this study has several limitations. First, it cannot be generalised and stated that other vulnerable young men will have similar experiences as those of the five young men in this study. It also seems artificial to perceive these men as a homogeneous group since they are all surrounded with different contexts and have their own unique life stories. Finally, the picture that has been drawn remains quite one-sided and exclusively positive. I have presented narratives about five young men, who were strategically selected due to their fascination with and interests in music and/or art. What about other young men who do not share these study participants' passionate relations to music and art? If I had chosen some other informants from the database, the outcome would presumably be quite different. Regarding this matter, I assume that discourses in aesthetic philosophy might have influenced the way that I have approached this task. I have noticed that the field of aesthetics, art and culture is often presented as something exclusively good. However, what happens when aesthetics becomes so intentionally good that makes it impossible to question its purpose or engage in any critical reflection? From this point of view, it may seem that there are a number of prevailing truths about aesthetics, art and culture for children and young people. Assessments and analyses that break with this standpoint might have a harder time achieving fame than contributions that praise the arts (Stavrum, 2013, pp. 156-166). From such a perspective, I have to admit that this contribution joins the ranks of such tributes.

At the outset, I asked what young men in vulnerable positions had to say about their experiences with aesthetics. Throughout the previous sections, I have therefore tried to emphasise the men's subjective perspectives by creating a picture of what aesthetic experiences seem to offer these young men, who can be identified as vulnerable for various reasons. The study's philosophical approach, emphasised by Dewey's (1958) naturalism, regards these experiences as true in the ontological sense. This is related to Dewey's $(1958$, p. 5) claim that aesthetic experiences, similar to other experiences, arise from people's encounters with nature and exist at par with material objects. Moreover, as I have tried to argue, aesthetics might contribute to something very important in this context, not a replacement for a safe or stable childhood and adolescence, but a source of processing emotions and creating meaning through the difficulties that life might bring. If such a view could be integrated into a pedagogical understanding, schools may increase their ability to meet the challenges of mental health and social equality. 


\section{REFERENCES}

Austring, B. D. \& Sørensen, M. (2006). Astetik og læring - Grundbog om æstetiske læreprocesser. [Aesthetics and learning - a textbook on aesthetic learning processes]. Hans Reizels Forlag.

Austring, B. D. \& Sørensen, M. (2010). Mot et læringsorientert estetikkbegrep. [Towards a learning-oriented concept on aesthetics]. (K. M. Thorbjørnsen, Trans.). In J. H. Sætre \& G. Salvesen (Eds.), Allmenn musikkundervisning: perspektiver på praksis (pp. 39-53). Gyldendal Akademisk.

Biesta, G., Bloomer, M., \& Lawy, R. (2004). 'School's just a catalyst': Knowledge, learning and identity, and the post-16 curriculum. Journal of Vocational Education \& Training, 56(2), 205-226. https://doi.org/10.1080/13636820400200254

Bunting, M., \& Moshuus, G. H. (2017). Young people's own stories about dropping out in Norway: An indirect qualitative approach. Acta Didactica Norge, 11(2), 1-20. https://doi.org/10.5617/adno.3182

Creswell, J. W. (2013). Qualitative inquiry \& research design: Choosing among five approaches. SAGE.

Csikszentmihalyi, M. (1990). Flow: The psychology of optimal experience (2nd ed.). Harper Perennial.

Dewey, J. (1934). Art as experience. The Berkley Publishing Group.

Dewey, J. (1958). Experience and nature (2nd ed.). Dover Publication.

Dewey, J. (2001). Erfaring og tenkning. [Experience and thinking]. In E. L. Dale (Ed.), Om utdanning (pp. 53-66). Gyldendal Akademisk.

Dewey, J. (2008). Å gjøre en erfaring: Fra Art as experience. [Having an experience: From Art as experience]. (K. Bale \& A. Bø-Rygg, Trans.). In K. Bale \& A. B ø-Rygg (Eds.), Estetisk teori- en antologi (pp. 196-213). Universitetsforlaget.

Fredricks, J. A., Blumenfeld, P. C., \& Paris, A. H. (2004). School engagement: Potential of the concept, state of the evidence. Review of Educational Research, 74(1), 59-109. https://doi.org/10.3102/00346543074001059

Green, J., Cross, R., Woodall, J., \& Tones, K. (2019). Health promotion - planning and strategies (4th ed.). SAGE.

Hammer, T., \& Hyggen, C. (2013). Ung voksen- risiko for marginalisering. [Young adult - risk of marginalisation]. In T. Hammer \& C. Hyggen (Eds.), Ung voksen og utenfor-Mestring og marginalitet på vei til voksenliv (pp. 13-27). Gyldendal Norsk Forlag.

Hegna, K., Eriksen, M. E., Sletten, M. A., Strandbu, Å., \& Ødegård, G. (2017). Ungdom og psykisk helse- endringer og kontekstuelle forklaringer. [Youth and mental health- changes and contextual explanations]. In M. Bunting \& G. H. Moshuus (Eds.), Skolesamfunnet (pp. 75-94). Cappelen Damm.

Hohr, H. (2010). The role of emotion in experience - comment on John Dewey's Arts as experience. In A. Østern \& H. Kaihovirta-Rosvik (Eds.), Arts education and beyond (pp. 21-42). Åbo Akademis Förlag.

Hohr, H. (2015). Estetisk oppdragelse og kunst [Aestehtic education and art]. Nordisk Tidsskrift for Pedagogikk og Kritikk, 1, 1-11. https://doi.org/10.17585/ntpk.v1.113

Kvale, S., \& Brinkmann, S. (2015). Det kvalitative forskningsintervju [The qualitative research interview]. (3rd ed.). (T. M. Anderssen \& J. Rygge, Trans.). Gyldendal Akademisk.

Langer, S. K. (1942). Philosophy in a new key: A study in the symbolism of reason, rite, and art. New American Library.

Markussen, E. (2016). Forskjell på folk. [Differences between "people"]. In K. Reegård \& J. Rogstad (Eds.), De frafalne (pp. 22-61). Gyldendal Akademisk.

Ministry of Education and Research. (2020). Health and life skills. https://www.udir.no/lk20/overordnetdel/prinsipper-for-laring-utvikling-og-danning/tverrfaglige-temaer/folkehelse-og-livsmestring/?lang=eng

Moshuus, G. H. (2012). Skulle jeg latt være å intervjue Sandra? Om etnografi på barnefattigdom og snøballen som stoppet. [Should I not have interviewed Sandra? About ethnography on child poverty and the snowball that stopped]. In E. Backe-Hansen \& I. Frønes (Eds.), Metoder og perspektiver i barne-og ungdomsforskning. Gyldendal Akademisk. 
Moshuus, G. H., \& Eide, K. (2016). The indirect approach: How to discover context when studying marginal youth. International Journal of Qualitative Methods, 15(1), pp. 1-10. https://doi.org/10.1177/1609406916656193

Norwegian Institute of Public Health. (2014). Folkehelserapporten 2014 - Helsetilstanden i Norge. [Report- Public Health in Norway 2014]. (Rapport 4/2014). https://www.fhi.no/globalassets/dokumenterfiler/rapporter/2014/folkehelserapporten-2014pdf.pdf?fbclid=IwAROphRMSwCnPxe91WxKQzp4OmkIvUBPJBvrjoLVw6NJvktkHg_2ukXUuptA

Norwegian Institute of Public Health. (2016, 12 April). Psykiske lidelser i Norge: Et folkehelseperspektiv. [Mental health in Norway: A public health perspective]. https://www.fhi.no/publ/eldre/psykiske-lidelser-i-norgeet-folkeh/

Norwegian Institute of Public Health. (2018, 5 October). Barn og unges helse: Oppvekst og levekår. [Children and youth's health: Adolescence and living conditions]. https://www.fhi.no/nettpub/hin/grupper/barnoppvekst/?term=\&h=1\#100000-barn-i-familier-med-lav-inntekt

Norwegian Institute of Public Health. (2018). Folkehelserapporten-Kortversjon: Helsetilstanden i Norge 2018. [Report- Public Health in Norway 2018]. (Rapport 2018). https://www.fhi.no/globalassets/dokumenterfiler/rapporter/2018/helsetilstanden-i-norge-20182.pdf

Norwegian Institute of Public Health. (2019, 8 August). Quality of life and mental health among children and adolescents. https://www.fhi.no/en/op/hin/groups/mental-health-children-adolescents/

Norwegian Institute of Public Health. (2020, 21 January). Suicide in Norway. https://www.fhi.no/en/op/hin/mental-health/suicide/

NOU 2019: 3. (2019). Nye sjanser- bedre læring: Kjønnsforskjeller i skoleprestasjoner og utdanningsløp. [New opportunities- improved learning: Gender differences in school achievement and education]. Ministry of Education and Research. https://www.regjeringen.no/no/dokumenter/nou-2019-3/id2627718/

Rasmussen, M., \& Dieserud, G. (2018). Etterlattes erfaringer ved selvmord for unge menn. [Survivors' experiences of suicide for young men]. Tidsskriftet den norske legeforening. http://doi.org/10.4045/tidsskr.17.0571

Regjeringen. (2020). Regjeringens handlingsplan for forebygging av selvmord 2020-2025. [The Government's strategy for suicide prevention 2020-2025]. https://www.regjeringen.no/no/dokumenter/regjeringenshandlingsplan-for-forebygging-av-selvmord-2020-2025/id2740946/

Ross, M. (1978). The creative arts. Heinemann Educational Books.

Ruud, E. (2011). Musikk, identitet og helse. Hva er sammenhengen? [Music, identity, and health. What is the connection?] In K. Stensæth \& L. O. Bonde (Eds.), Musikk, helse og identitet (pp. 13-23). (NMH Publications 2011: 3). Centre for Music and Health Publication Series. https://nmh.brage.unit.no/nmhxmlui/bitstream/handle/11250/172301/Ruud_2011.pdf?sequence=1\&is Allowed $=\mathrm{y}$

Stavrum, H. (2013). Begeistringsforskning eller evalueringstyranni? Om kunnskap om kunst for barn og unge. [Enthusiasm research or evaluation tyranny? About knowledge on art for children and young people]. Nordisk kulturpolitisk tidsskrift, 16(1), 54-170. https://www.idunn.no/nkt/2013/01/begeistringsforskning_eller_evalueringstyranni_om_kunnskap

Thagaard, T. (2013). Systematikk og innlevelse: En innføring i kvalitativ metode. [Systematic and immersion: An introduction to qualitative method] (4th ed.). Fagbokforlaget.

The Norwegian Directorate for Education and Training. (2020a). Musikk- Tverrfaglige temaer (MUS01-02). [Music curriculum- Interdisciplinary topics]. https://www.udir.no/lk20/mus01-02/om-faget/tverrfaglige-temaer

The Norwegian Directorate for Education and Training. (2020b). Kunst \& Håndverk- Tverrfaglige temaer (KHV01-02). [Art and Crafts curriculum- Interdisciplinary topics]. https://www.udir.no/lk20/khv0102/om-faget/tverrfaglige-temaer

University of South-Eastern Norway. (n.d.a). Marginalisation and Co-created Education. Retrieved February 8, 2020, from https://www.usn.no/english/research/projects/marginalisation-and-co-created-educationmace/ 
University of South-Eastern Norway. (n.d.b). Young people, education and early school leaving in Telemark. Retrieved February 9, 2020, from https://www.usn.no/english/research/our-research/kindergardenschools-and-higher-education/childhood-and-education/young-people-education-and-early-schoolleaving-in-telemark-ungsa

Winnicott, D. W. (1971). Lek och verklighet. [Playing and reality]. (I. Lòfgren \& A. Jemstedt, Trans.). Natur och Kultur. 